\title{
Análise do percentual de gordura do leite no diagnóstico precoce de enfermidades podais em vacas leiteiras
}

Mirian Rodrigues, Fábio Henrique Bezerra Ximenes, José Ricardo Barbosa Silva, Celso Antonio Rodrigues

Departamento de Cirurgia e Anestesiologia Veterinária, Faculdade de Medicina Veterinária e Zootecnia, Universidade Estadual Paulista (UNESP), Botucatu, SP, Brasil

*Autor correspondente

e-mail: mrodrigues@fmvz.unesp.br

\section{Resumo}

As lesões nos cascos podem ser divididas em não infecciosas e infecciosas, que resultam em dificuldade locomotora devido à dor. As causas das afecções podais são multifatoriais e complexas, oriundas de uma combinação de fatores chamados fatores de risco. 0 grande interesse do mercado pelo leite é expresso principalmente na qualidade, o que influencia o manejo dos animais, que são cada vez mais exigidos metabolicamente. Um dos principais parâmetros utilizados por programas de qualidade de leite está fundamentado na gordura, sendo que realizar testes diários pode ser útil para monitorar o balanço nutricional, o equilíbrio dos nutrientes e também detectar possíveis falhas de manejo. 0 presente trabalho objetivou a identificação precoce de lesões podais infecciosas e secundárias à laminite, em vacas leiteiras de alta produção, da raça Holandesa, a partir de alterações na porcentagem de gordura do leite produzido. Foram selecionadas 245 vacas Holandesas de alta produção leiteira, que não apresentaram em 308 dias de lactação nenhuma enfermidade que pudesse interferir nos resultados mensurados, como mastite, deslocamento de abomaso, pneumonia, hipocalcemia, retenção de placenta, metrite, diarreia e cetose. Os dados da porcentagem de gordura do leite foram mensurados mensalmente e avaliados nos cinco meses anteriores à ocorrência da lesão podal. Desta forma, realizou-se pareamento entre casos (com lesão) e controles (sem lesão), ou seja, dependendo da semana de ocorrência de um caso com laminite ou lesão infecciosa, foi encontrado, aleatoriamente, um controle (sem lesão) na mesma semana de lactação. A ocorrência e classificação das afecções podais foram realizadas durante todo o período de lactação e apenas a primeira ocorrência foi registrada buscando a identificação de quaisquer alterações anteriores à lesão, não sendo isto possível nas recidivas. A lesão infecciosa (LI) de maior incidência foi a dermatite digital (71,42\%), seguida da dermatite interdigital (28,57\%). Nas lesões laminite (LL), a de maior incidência foi a úlcera de 
sola (52,38\%) seguida da doença da linha branca (33,33\%) e úlcera de pinça (14,28\%). A dermatite digital e a úlcera de sola foram as de maior incidência, 75\% e 64\%, respectivamente. Em relação à análise da gordura no leite, esta não apresentou diferença entre os animais com e sem lesão podal neste estudo. Os animais que apresentaram LL obtiveram $0,11 \%$ de gordura a menos do que os animais sem lesão, enquanto os animais LI apresentaram $0,12 \%$ de gordura a menos do que os animais SL, sendo aceitável variação de $0,2 \%$ para mais ou para menos no valor da gordura, o que torna a variação de resultados aceitáveis. Testes diários do leite são necessários para que a análise seja útil e mais fidedigna. 